\title{
First Total Synthesis of Neoantimycin
}

\author{
Hikaru Ogawa, Hideo Iio, Yoshinosuke Usuki
}

\begin{tabular}{|c|l|}
\hline Citation & Chemistry Letters, $44(9) ; 1214-1216$ \\
\hline Issue Date & 2015 \\
\hline Type & Journal article \\
\hline Text version & author \\
\hline Rights & $\begin{array}{l}\text { C } 2015 \text { The Chemical Society of Japan. This article may be downloaded for } \\
\text { personal use only. Any other use requires prior permission of The Chemical } \\
\text { Society of Japan. The following article has been submitted to 'Chemistry Letters'. } \\
\text { After it is published, it will be found at https://doi.org/10.1246/cl.150509 }\end{array}$ \\
\hline DOI & \begin{tabular}{l}
$10.1246 /$ cl.150509 \\
\hline
\end{tabular} \\
\hline
\end{tabular}

\author{
Self-Archiving by Author(s) \\ Placed on: Osaka City University
}

Hikaru Ogawa, Hideo Iio, Yoshinosuke Usuki. (2015). First Total Synthesis of Neoantimycin.

Chemistry Letters. 44, 1214-1216. 


\title{
First Total Synthesis of Neoantimycin
}

\author{
Hikaru Ogawa, Hideo Iio, and Yoshinosuke Usuki* \\ Division of Molecular Materials Science, Graduate School of Science, Osaka City University, \\ 3-3-138 Sugimoto, Sumiyoshi-ku, Osaka 558-8585 \\ ( E-mail: usuki@sci.osaka-cu.ac.jp)
}

The first total synthesis of neoantimycin (1), an unusual ring-extended antibiotic of the antimycin class, has been achieved, wherein intramolecular transesterification was utilized for construction of the 15-membered tetralactone core.

Neoantimycin (1) is a rare and unusual ring-extended member of the antimycin class. First isolated in 1967 from a South American soil isolate of Streptomyces orinoci, ${ }^{1}$ the partial configuration of $\mathbf{1}$ was assigned in 1969 by preparative-scale degradation that yielded methyl $(S)-2-$ hydroxyisovalerate and methyl $(2 S, 3 S)$-2-hydroxy-3-methylvalerate. ${ }^{2}$ At that time, an L-Thr configuration was also asserted but not proven. A subsequent study using NOE experiments, reported by Takeda in 1998, attributed a $3 S, 4 S$ configuration to the 3,4-dihydroxy-2,2-dimethyl-5phenylvaleric acid residue in neoantimycin. ${ }^{3}$ Literature references to 1 were thus limited, but the recent discovery of prunustatin A (2) as a selective GRP78 molecular chaperone down-regulator, ${ }^{4}$ which could lead to the development of new approaches toward combatting cancer, highlights the potential of this class as research probes (Figure 1). As an extension of our synthetic studies on prunustatin A (2), ${ }^{5}$ we have been engaged in studies directed toward the synthesis and structure determination of $\mathbf{1}$. During our pursuit of a total synthesis, Capon reported all configurational assignments of $\mathbf{1}$ based on spectroscopic analysis and micro-scale degradation, and its inhibitory activity toward K-Ras. ${ }^{6}$ We then focused on a synthetic confirmation on the stereochemical structure of $\mathbf{1}$. Herein, we report the first total synthesis of neoantimycin (1).

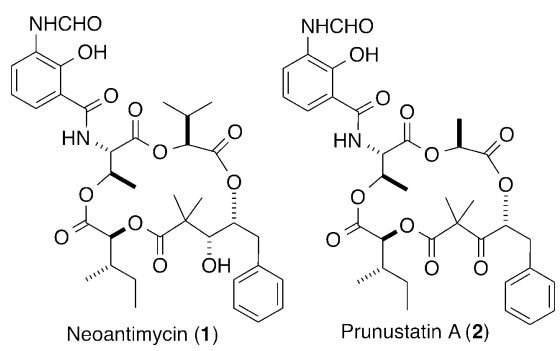

Figure 1. Structures of neoantimycin (1) and prunustatin A (2).

Preliminary molecular mechanics calculations suggest that the ring-closing precursors prefer a liner, extended conformation due to the gem-dimethyl groups at $\mathrm{C} 11$. Therefore we adopted synthetic strategy for 1 that involves cyclization via transesterification of $\beta$-keto ester $\mathbf{7}$ followed by the late-stage introduction of the gem-dimethyl groups at C11 (Scheme 1). Transesterification of $\beta$-keto ester mediated with metal salt would proceed under mild conditions, which minimize the epimerization at other stereogenic centers.

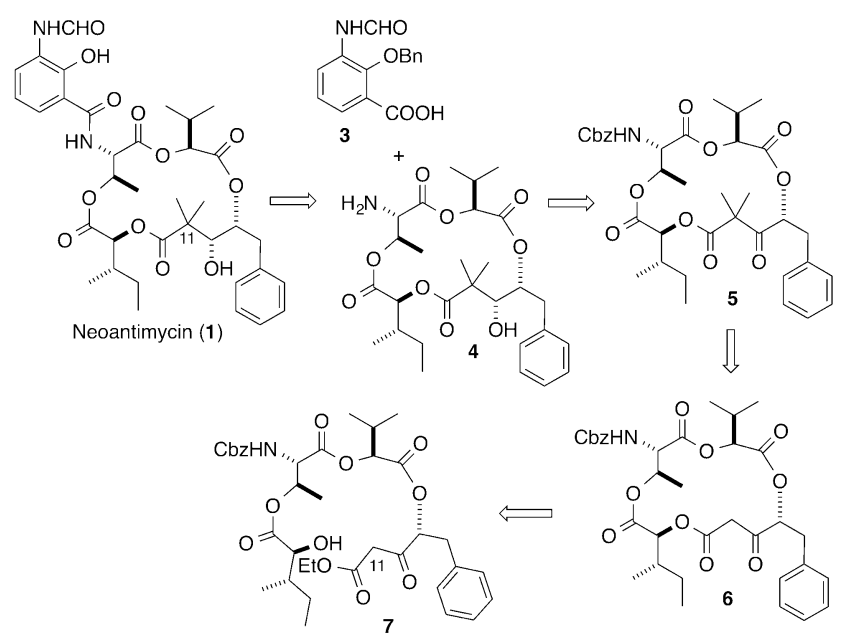

Scheme 1. Retrosynthetic analysis of neoantimycin (1).

Our total synthesis of $\mathbf{1}$ commenced with L-valine (Scheme 2). Treatment of L-valine with $\mathrm{NaNO}_{2}$ in acetic acid provided acetate $\mathbf{8},{ }^{7}$ which was converted to tert-butyl ester $\mathbf{9}$. Hydrolysis of the acetyl group with $\mathrm{K}_{2} \mathrm{CO}_{3}$ in aq $\mathrm{MeOH}$ resulted in the formation of $\mathbf{1 0}$ in $\mathbf{7 3 \%}$ yield.

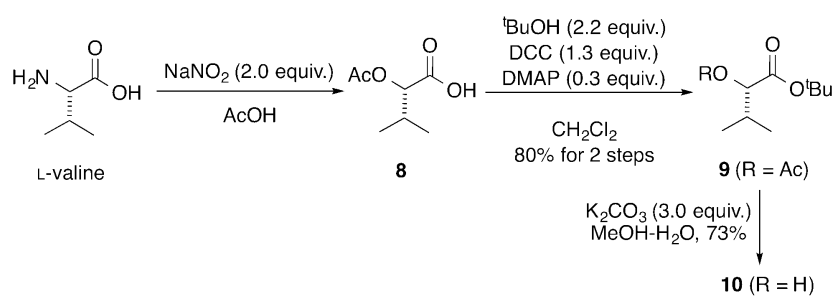

Scheme 2. Preparation of tert-butyl (S)-2-hydroxy-3methylbutyrate $\mathbf{1 0}$.

Condensation of $\mathbf{1 0}$ with $O$-TBS-protected $N$-Cbz-Lthreonine $\mathbf{1 1}^{8}$ in the presence of DCC and DMAP provided $\mathbf{1 2}$ in $93 \%$ yield (Scheme 3). Removal of the TBS group was achieved with HF-pyridine to afford $\mathbf{1 3}$ in $88 \%$ yield. Treatment of bis- $O$-TBS-protected L-isoleucine derivative 14 with oxalyl chloride in the presence of a catalytic amount of DMF afforded the corresponding acid chloride, ${ }^{9}$ which was esterified with $\mathbf{1 3}$ to provide $\mathbf{1 5}$ in $82 \%$ yield. The tert-butyl group was removed with TESOTf and 2,6-lutidine to give $\mathbf{1 6}$ in $80 \%$ yield. $^{10}$ 


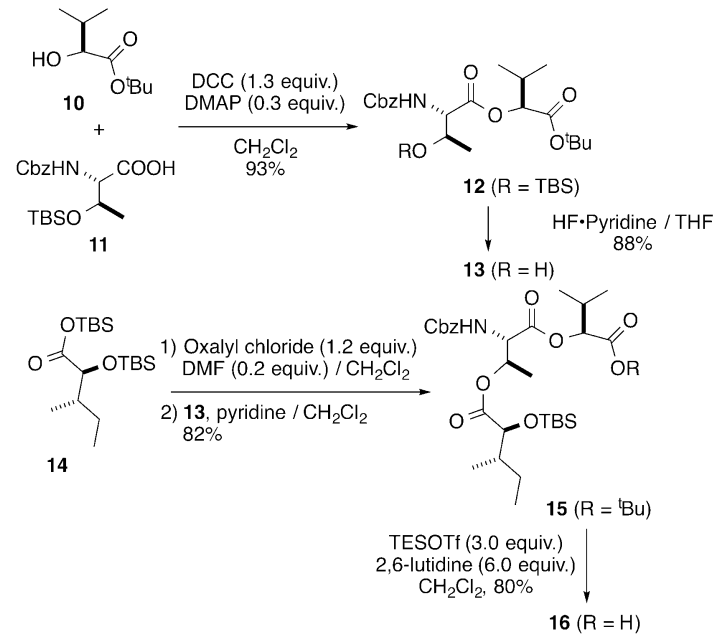

Scheme 3. Preparation of acid $\mathbf{1 6 .}$

The ring-closure precursor $\mathbf{7}$ was obtained by condensation of 16 with $17^{5 \mathrm{~b}}$ in the presence of DCC and DMAP and subsequent removal of the TBS group with HF in $\mathrm{CH}_{3} \mathrm{CN}$ (Scheme 4). A mixture of 7 and anhydrous $\mathrm{CuSO}_{4}(20$ equiv.) in toluene was heated under reflux. The desired transesterification proceeded smoothly to provide the 15membered tetralactone 6 in $88 \%$ yield. $^{11}$

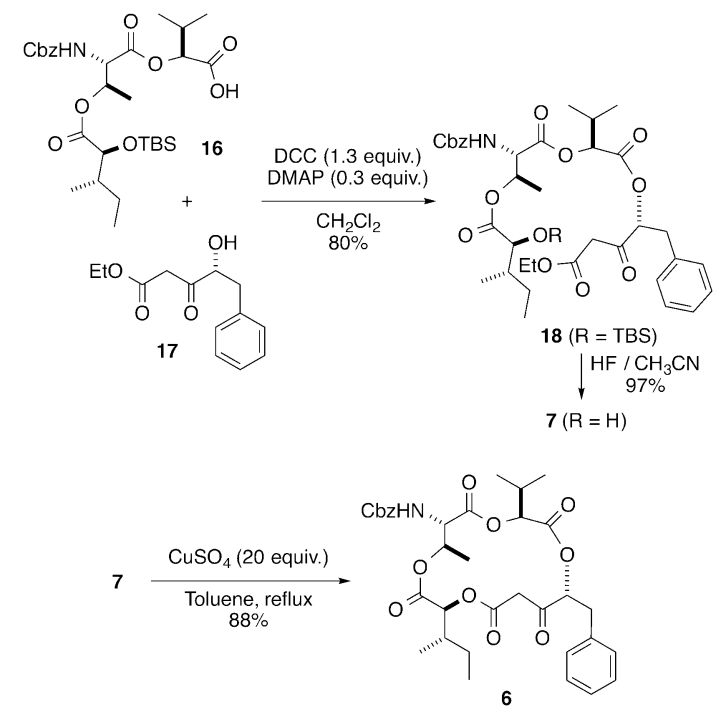

Scheme 4. Preparation and transesterification of 7.

Introduction of gem-dimethyl groups at $\mathrm{C} 11$ was achieved by treatment of 6 with iodomethane ( 5 equiv.) and $\mathrm{K}_{2} \mathrm{CO}_{3}$ (10 equiv.) in DMSO at $40{ }^{\circ} \mathrm{C}$ for $4 \mathrm{~h}$ (Scheme 5). The desired product $\mathbf{5}$ was obtained in $70 \%$ yield. Reduction of $\mathbf{5}$ with $\mathrm{NaBH}_{4}$ proceeded smoothly to provide the corresponding alcohol 19 in $78 \%$ yield as a single diastereomer. Subsequent treatment of 19 with $1 \mathrm{M}$ aq $\mathrm{NaOH}$ resulted in formation of the five-membered lactone $\mathbf{2 0}$, which was alternatively provided by reductive removal of the benzyl group in $\mathbf{2 1}^{12}$; the configuration at $\mathrm{C} 10$ was thus confirmed.
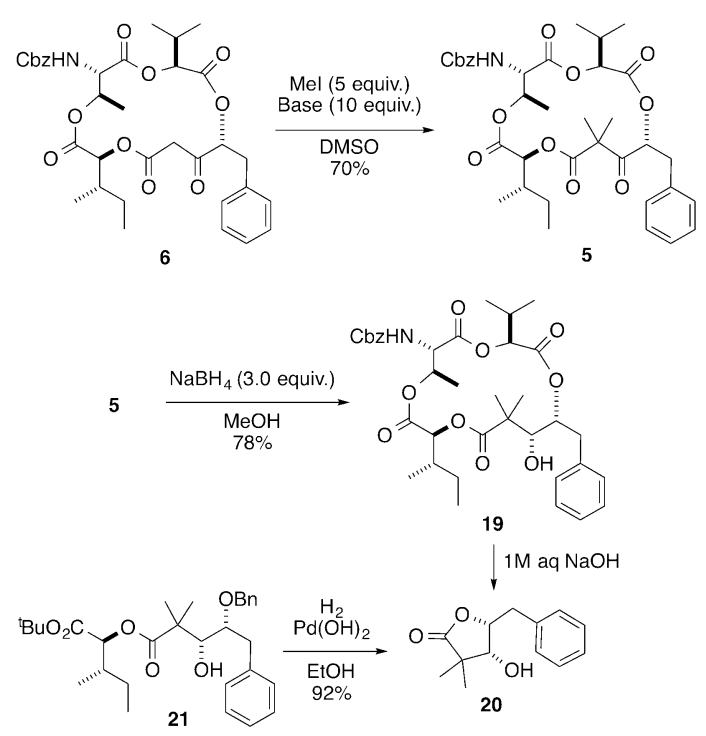

Scheme 5. Introduction of the gem-dimethyl groups and reduction with $\mathrm{NaBH}_{4}$.

Molecular mechanics calculations on $\mathbf{5}$ were conducted using the MMFF94 force field. ${ }^{13}$ A possible conformation, as shown in Figure 2, clearly explains the high stereoselectivity observed in the reduction of 5: one of the gem-dimethyl groups hinders the approach of hydride to the alpha face of the carbonyl moiety.

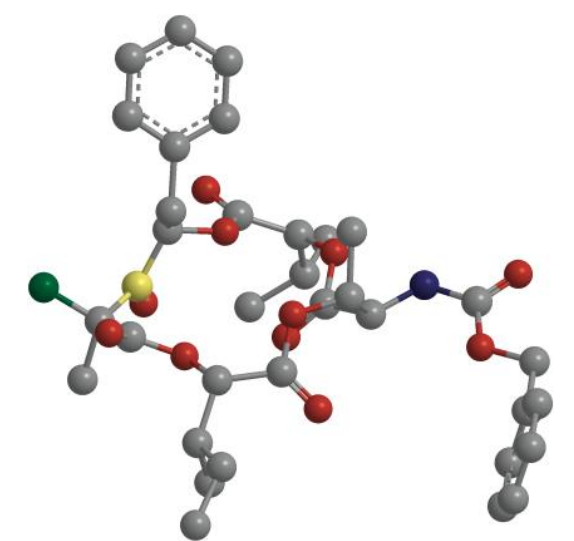

Figure 2. A possible conformation of $\mathbf{5}$ calculated with the MMFF94 force field. Green: one of the gem-dimethyl group, Yellow: carbonyl carbon.

To complete the synthesis of $\mathbf{1}$, the $\mathrm{Cbz}$ group of $\mathbf{1 9}$ was removed by hydrogenolysis with $\mathrm{Pd}(\mathrm{OH})_{2}$ in EtOAc to afford 4. The subsequent condensation of $\mathbf{4}$ and $3^{14}$ was achieved using EDCI, HOBt, and NMM in DMF to provide the corresponding $\mathbf{2 2}{ }^{15}$ in $79 \%$ yield. Removal of the benzyl ether protecting group using $\mathrm{Pd}(\mathrm{OH})_{2}$ in EtOAc afforded neoantimycin (1) in $78 \%$ yield (Scheme 6). The spectral data of synthetic $\mathbf{1}$ were identical to those reported for a natural sample. ${ }^{15,16}$ The optical rotation of synthetic $1\left([\alpha]_{\mathrm{D}}+24.8\right.$, c $\left.0.11, \mathrm{CHCl}_{3}\right)$ was consistent with that of the natural product $\left([\alpha]_{\mathrm{D}}+21.2, \mathrm{c} 0.01, \mathrm{CHCl}_{3}\right)^{2}$ 


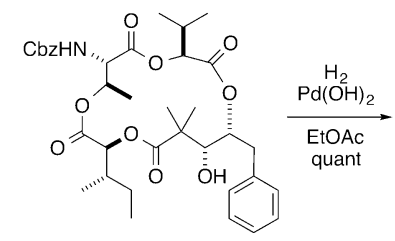

19

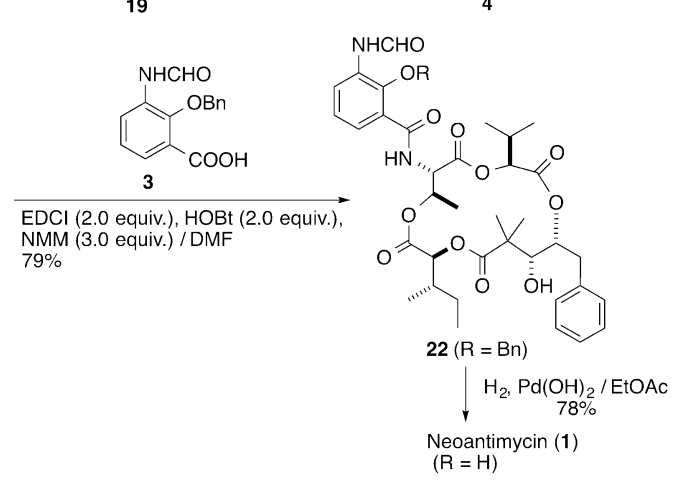

Scheme 6. Endgame towards Neoantimycine (1)

In summary, the first total synthesis of neoantimycin (1) has been achieved. Comparison of our spectroscopic data with those reported for natural verified the structure of the natural product. Further studies are now in progress, and the results will be reported in due course.

\section{References and Notes}

G. Cassinelli, A. Grein, P. Orezzi, P. Pennella, A. Sanfilippo, Arch. Mikrobiol. 1967, 55, 358.

2 L. Caglioti, D. Misiti, R. Mondelli, A. Selva, F. Arcamone, G. Cassinelli, Tetrahedron 1969, 25, 2193.

3 Y. Takeda, T. Masuda, T. Matsumoto, Y. Takechi, T. Shingu, H. G. Floss, J. Nat. Prod. 1998, 61, 978.

4 a) Y. Umeda, S. Chijiwa, K. Furihata, K. Furihata, S. Sakuda, H. Nagasawa, H. Watanabe, K. Shin-ya, J. Antibiot. 2005, 58, 206; b) Y. Umeda, K. Furihata, S. Sakuda, H. Nagasawa, K. Ishigami, H. Watanabe, M. Izumikawa, M. Takagi, T. Doi, Y. Nakao, K. Shinya, Org. Lett. 2007, 9, 4239.

5 a) T. Inaoka, Y. Tei, Y. Usuki, H. Iio, Abstracts of Papers, 457, 52nd Symposium on the Chemistry of Natural Products, Shizuoka, 2010; b) Y. Usuki, H. Ogawa, K.-I. Yoshida, T. Inaoka, H. Iio, Asian J. Org. Chem. in press.

6 A. A. Salim, K.-J. Cho, L. Tan, M. Quezada, E. Lacey, J. F. Hancock, R. J. Capon, Org. Lett. 2014, 16, 5036.

7 A. B. Hughes, M. M. Sleebs, J. Org. Chem. 2005, 70, 3079.

8 T. Sengoku, Y. Nagae, Y. Ujihara, M. Takahashi, H. Yoda, J. Org. Chem. 2010, 77, 4391.

9 A. Murai, Y. Amino, T. Ando, J. Antibiot. 1985, 58, 1610.

10 M. Oikawa, T. Ueno, H. Oikawa, A. Ichihara, J. Org. Chem. 1995, 60, 5048.

11 B. P. Bandgar, V. S. Sadavarte, L. S. Uppala, Synth. Commun. 2001, 31, 2063.

12 S. Yamakoshi, E. Kawanishi, Tetrahedron Lett. 2014, 55, 1175.

13 T. A. Halgren, J. Comput. Chem. 1996, 17, 490.

14 G. R. Pettit, T. H. Smith, S. Feng, J. C. Knight, R. Tan, R. K. Pettit, P. A. Hinrichs, J. Nat. Prod. 2007, 70, 1073.

15 The ${ }^{1} \mathrm{H}$ and ${ }^{13} \mathrm{C}$ NMR spectra indicated that it existed as a ca. 9:1 mixture of two rotamers.

16 1: m.p. $120-121^{\circ} \mathrm{C}$, natural ${ }^{2}$ : m.p. $121-122^{\circ} \mathrm{C} ;[\alpha]_{\mathrm{D}}=+53.3$ (c 0.30 , $\left.\mathrm{CHCl}_{3}\right)$, natural ${ }^{2}:[\alpha]_{\mathrm{D}}=+58.3\left(\mathrm{c} 1, \mathrm{CHCl}_{3}\right) .{ }^{1} \mathrm{H}$ NMR $(600 \mathrm{MHz}$, $\left.\mathrm{CDCl}_{3}\right) \delta 12.63(1 \mathrm{H}, \mathrm{s}), 8.56(1 \mathrm{H}, \mathrm{d}, J=8.1 \mathrm{~Hz}), 8.50(1 \mathrm{H}, \mathrm{d}, J=$ $1.7 \mathrm{~Hz}), 7.92(1 \mathrm{H}, \mathrm{s}), 7.32(1 \mathrm{H}, \mathrm{dd}, J=8.1,1.5 \mathrm{~Hz}), 7.29-7.19(5 \mathrm{H}$, m), $7.14(1 \mathrm{H}, \mathrm{d}, J=8.7 \mathrm{~Hz}), 6.94(1 \mathrm{H}, \mathrm{t}, J=8.1 \mathrm{~Hz}), 5.73(1 \mathrm{H}, \mathrm{qd}$, $J=6.5,2.6 \mathrm{~Hz}), 5.52(1 \mathrm{H}, \mathrm{dd}, \mathrm{J}=9.6,5.8 \mathrm{~Hz}), 5.44(1 \mathrm{H}, \mathrm{d}, J=3.5$ $\mathrm{Hz}), 5.12(1 \mathrm{H}, \mathrm{dd}, J=8.7,2.6 \mathrm{~Hz}), 4.66(1 \mathrm{H}, \mathrm{d}, J=8.3 \mathrm{~Hz}), 3.54$ $(1 \mathrm{H}, \mathrm{d}, J=12.4 \mathrm{~Hz}), 3.18(1 \mathrm{H}, \mathrm{d}, J=12.4 \mathrm{~Hz}), 3.16(1 \mathrm{H}, \mathrm{dd}, J=$ 14.0, $9.6 \mathrm{~Hz}), 2.94(1 \mathrm{H}, \mathrm{dd}, J=14.0,5.8 \mathrm{~Hz}), 1.99-1.93(1 \mathrm{H}, \mathrm{m})$,
1.83-1.78 (1H, m), 1.55-1.48 (1H, m), $1.41(3 \mathrm{H}, \mathrm{s}), 1.33(1 \mathrm{H}, \mathrm{d}, J$ $=6.5 \mathrm{~Hz}), 1.30(3 \mathrm{H}, \mathrm{s}), 1.25-1.16(1 \mathrm{H}, \mathrm{m}), 0.89(3 \mathrm{H}, \mathrm{d}, J=6.9 \mathrm{~Hz})$, $0.88(3 \mathrm{H}, \mathrm{t}, J=7.5 \mathrm{~Hz}), 0.81(3 \mathrm{H}, \mathrm{d}, J=6.9 \mathrm{~Hz}), 0.45(3 \mathrm{H}, \mathrm{d}, J=$ $6.9 \mathrm{~Hz}) ;{ }^{13} \mathrm{C}$ NMR $\left(150 \mathrm{MHz}, \mathrm{CDCl}_{3}\right) \delta 176.90,170.20,168.27$, $168.27,168.10,158.93,150.53,136.74,129.20,128.62,127.34$ $126.85,124.73,120.25,118.96,112.85,79.05,77.00,76.70,75.10$, $72.38,71.79,55.16,45.39,40.26,35.97,30.68,26.89,24.73,21.87$, $18.70,16.27,16.09,14.30,10.52$; HR-ESI-MS: calcd. For $\mathrm{C}_{36} \mathrm{H}_{47} \mathrm{~N}_{2} \mathrm{O}_{12}$ : 699.3124; found $699.3224[\mathrm{M}+\mathrm{H}]^{+}$. 


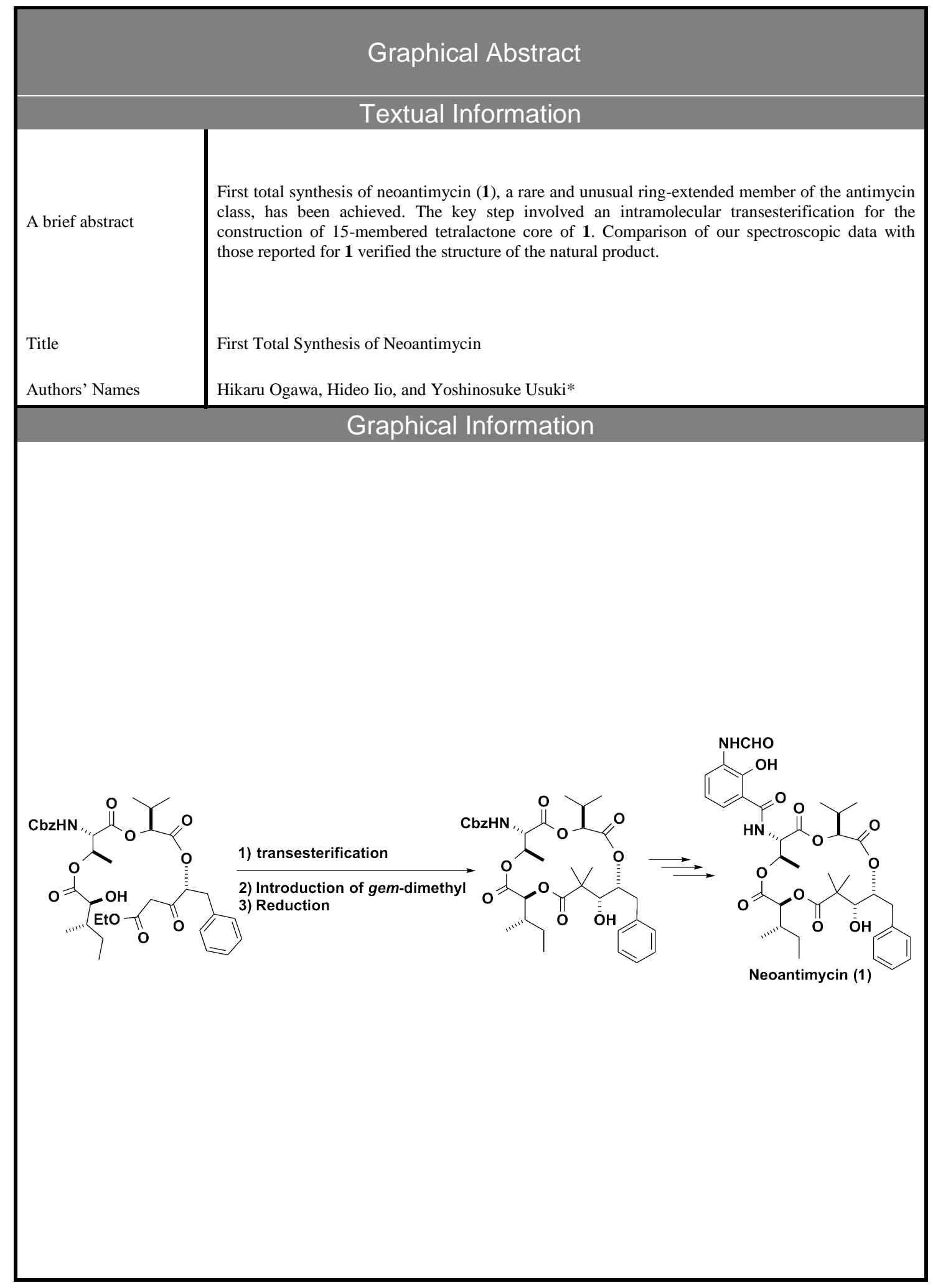

